\title{
Diferenças e Semelhanças entre os Sistemas da Civil Lawe da Common Law
}

\section{ANA CAROLINA OLIVEIRA}

Advogada, Mestranda em Direito e Políticas Públicas pelo UniCEUB, Professora de Direito Constitucional e Direitos Humanos da Faciplac, Pós-Graduada em Contratos e Responsabilidade Civil no IDP - Instituto de Direito Público.

Submissão: 19.06 .2014

Decisão Editorial: 29.04.2015

Comunicação ao autor: 29.04.2015

RESUMO: 0 presente estudo pretende traçar uma análise sobre as diferenças e semelhanças entre os sistemas da civil law e da common law. Assim, indaga-se: a técnica do precedente da common law pode ser usada na civil law? Após a análise sobre as semelhanças e divergências entre esses dois modelos, concluiu-se que a adoção de um sistema de precedentes no Direito brasileiro não decorre da cultura existente no país, mas apenas de uma importação de um instituto bem-sucedido em um direito estrangeiro.

PALAVRAS-CHAVE: Civil law; common law; divergências; precedentes.

ABSTRACT: This work intends to analyze the differences and similarities between the systems of civil law and the common law. Thus, it aims at showing possible answers to the following questions: can the rule of precedent be employed in the civil law. So, after analizing the similarities and differences between these two models, it was concluded that the adoption of the rule of precedent in Brazilian law does not arise from the culture in the country, but only from a introduction of a well succeeded common law's institute.

KEYWORDS: Civil law; common law; differences; similarities.

SUMÁRIO: Considerações introdutórias; 1 As famílias da common law e romano-germânica; 1.1 A família romano-germânica; 1.2 A família da common law; 20 precedente judicial nos sistemas de common law; 3 A formação do processo decisório no sistema da common law nos Estados Unidos; 4 A vinculação aos precedentes no Direito brasileiro; Conclusões; Referências.

\section{CONSIDERAÇÕES INTRODUTÓRIAS}

O presente estudo pretende traçar uma análise sobre as diferenças e semelhanças entre os sistemas da civil law e da common law. Nesse sentido, pretende discutir e analisar, apresentando possíveis respostas, às seguintes perguntas: há tendência à aproximação desses sistemas? A técnica do precedente da common law pode ser usada na civil law? 
A busca por maior segurança nas decisões judiciais e a otimização destas, evitando-se o desnecessário exame de casos idênticos já anteriormente decididos e, consequentemente, por uma maior segurança jurídica em prol da sociedade, levou vários países a adotarem mecanismos com o objetivo de uniformizar a jurisprudência ${ }^{1}$. Nas palavras de Jorge Amaury Nunes, percebe-se hoje, no cenário atual, uma crise nos ordenamentos jurídicos, em que inúmeros conflitos sociais deságuam no Judiciário ${ }^{2}$ e este se depara, cada dia mais, com mais conflitos, com mais processos.

Diante desse cenário, são levantados inúmeros fatores que acarretam a ausência da eficiência do Poder Judiciário, entre eles a corrupção no seio do Poder Judiciário, a má formação do bacharel em Direito, os inúmeros recursos e sua larga utilização com o intuito meramente protelatório, entre outros. Não se pretende analisar, nesse trabalho, esses fatores, mas sim o problema que eles geram: a insegurança jurídica e quais os mecanismos jurídicos podem ser utilizados ou não para diminuí-la.

O sistema jurídico inglês, ao adotar a técnica dos precedentes ou da stare decisis, segundo a qual as decisões judiciais sempre serão baseadas em decisões anteriores de mesma natureza, possibilita que "os indivíduos e entidades podem se permitir melhor ordenar suas questões e negócios" ${ }^{\prime 3}$. Isso porque o uso dos precedentes permite uma maior previsibilidade na maneira pela qual uma controvérsia poderá ser decidida, oferecendo ${ }^{4}$, assim, uma garantia de certa segurança jurídica.

Nesse contexto, o presente estudo pretende averiguar se é possível a adoção do sistema de precedentes, originário do modelo da common law, no Direito brasileiro, no qual se adota o modelo do civil law, com o objetivo de garantir a segurança jurídica. Para tanto, essa análise se inicia com um breve histórico do sistema da common law e do civil law, suas origens, seus conceitos e sua aplicação nos dias de hoje. Após isso, passa-se ao estudo do sistema jurídico brasileiro, por meio de um breve histórico, para, ao final, identificar a possibilidade ou não da adoção do sistema dos precedentes no Direito brasileiro e extrair algumas conclusões e outros questionamentos.

\section{AS FAMÍLIAS DA COMMON LAWE ROMANO-GERMÂNICA}

A partir de um estudo de direito comparado, René David propõe-se a fornecer uma obra que analisa os diversos direitos de cada Estado. Assim, para facilitar seu estudo, o autor agrupa esses direitos em famílias, sobre as quais ex-

1 STRECK, Lenio Luiz. Súmulas no direito brasileiro: eficácia, poder e função: a ilegitimidade constitucional do efeito vinculante. 2. ed. Porto Alegre: Livraria do Advogado, 1998. p. 93.

2 NUNES, Jorge Amaury Maia. Segurança jurídica e súmula vinculante. São Paulo: Saraiva, 2010. p. 05.

3 Apud NUNES, Jorge Amaury Maia. Op. cit., p. 121.

4 Apud NUNES, Jorge Amaury Maia. Op. cit., p. 121. 
plica que "não há concordância sobre o modo de efetuar este agrupamento, e sobre quais as famílias de direitos se deve, por conseguinte, conhecer" ${ }^{\prime \prime}$. Assim, para ele, o agrupamento dos direitos em família é o meio próprio para facilitar, reduzindo-os a um número restrito de tipos, para facilitar sua compreensão e apresentação ${ }^{6}$.

Com base nesse estudo, René David trata da família romano-germânica, da família da common law e da família dos direitos socialistas. Importante ressaltar, como o próprio autor destaca, que essas famílias são refletem toda a realidade do mundo contemporâneo, mas servem para apresentar um quadro com as principais regras, características e significados ${ }^{7}$.

Nesse ponto, nesse estudo serão apenas analisadas as famílias romano-germânicas e a da common law, já que estão relacionadas com o presente tema.

\subsection{A FamílLa ROMANO-GERMÂNICA}

A família romano-germânica agrupa os países que tiveram a ciência do direito concebida sobre a base do direito romano, tendo seu berço na Europa ${ }^{8}$. Essa família se caracteriza pelo fato de suas regras de direito serem concebidas como regras de conduta, ligadas a preocupações morais e de justiça, além de elaborarem seus direitos visando à regulação das relações entre os cidadãos ${ }^{9}$.

Embora a família romano-germânica tenha conquistado vastos territórios, vários desses países receberam o direito europeu de forma parcial, já que existia, antes dessa recepção, uma civilização autóctone, que comportava certas concepções de agir e viver e certas instituições. Logo, esses países criaram um novo direito em relação àqueles que constituem a sua aplicação na Europa, pois mantiveram seus princípios tradicionais ${ }^{10}$. É possível afirmar que os países que foram colonizados por países tipicamente da família romano-germânica adotam suas principais ideias e fundamentos, mas com algumas ressalvas devidas aos seus contextos históricos.

Entre esses países que sofreram essa recepção parcial das normas do direito romano-germânico pode-se citar o caso brasileiro, uma vez que este sofreu colonização portuguesa. Explica René David que "as colônias espanholas, portuguesas, francesas e holandesas da América aceitaram de modo natural as

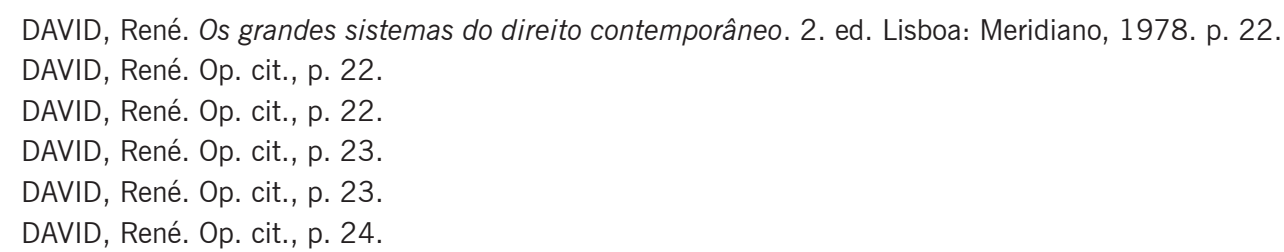


concepções jurídicas típicas da família romano-germânica"11. Nesse ponto, o próprio autor reconhece que a questão que se levanta "é somente a de saber em que medida as condições próprias da América, muito diferentes das do meio europeu, podem conduzir" a uma certa originalidade em relação aos direitos europeus da família romano-germânica ${ }^{12}$.

Verifica-se que os brasileiros da primeira geração de legisladores e juristas são fruto da ideia portuguesa de compilar as regras jurídicas em uma espécie de codificação para reformular o ensino do direito pátrio ${ }^{13}$. Isso porque esses operadores do direito foram socializados em Coimbra. Neste ambiente, como explica José Reinaldo Lima Lopes, "os primeiros cursos jurídicos brasileiros, de cuja criação participam homens que estudaram na Coimbra reformada, refletem esta reserva oitocentista ao direito romano"14. Tem-se, assim, a nítida influência que o Direito brasileiro recebeu da família romano-germânica.

Também explica Lenio Luiz Streck que, no ordenamento jurídico brasileiro, filiado ao sistema romano-germânico, ocorreu um movimento similar ao ordenamento jurídico da França e da Alemanha, que pretendiam construir o Direito baseado no code. Portanto, no Direito brasileiro, a rigor, a fonte primordial é a lei ${ }^{15}$. Assim, em Roma, berço da família romano-germânica, adotou-se como fonte do direito uma série de textos que abrangiam tanto legislação como doutrina ${ }^{16}$. Nesse sistema, "quem determinava o direito era um poder superior, que manifestava sua vontade pela positivação das normas de conduta"17. Por isso a família romano-germânica é caracterizada pela ideia de direito codificado, positivado.

Não restam dúvidas de que o Direito brasileiro sofreu influência direta e inicial dos direitos europeus da família romano-germânica, o que justifica, mais uma vez, a análise sobre a aplicabilidade de um instituto típico do direito inglês, o sistema de precedentes, no Direito brasileiro, de origem romano-germânica.

\subsection{A famílLA DA COMMON LAW}

Já a família que comporta o direito inglês é a conhecida família da common law. Nesse ponto, importante trazer a ressalva feita por José Rogério Cruz e Tucci de que o sistema da common law abrange as estruturas judiciárias da

11 DAVID, René. Op. cit., p. 77.

12 DAVID, René. Op. cit., p. 77.

13 LOPES, José Reinaldo de Lima. O direito na história: lições introdutórias. 4. ed. São Paulo: Atlas, 2012. p. $216 / 217$.

14 LOPES, José Reinaldo de Lima. Op. cit., p. 217.

15 STRECK, Op. cit., p. 77/78.

16 SABINO, Marco Antonio da Costa. O precedente jurisdicional vinculante e sua força no Brasil. Revista Dialética de Direito Processual Civil, n. 85, p. 53, abr. 2010, fls. 51/72.

17 SABINO, Marco Antonio da Costa. Op. cit., fls. 51/72. 
Inglaterra, País de Gales, Irlanda do Norte e Escócia, que, embora possuam peculiaridades em razão de vicissitudes históricas, todas elas são baseadas no direito casuístico, ou case law ${ }^{18}$. Assim, a common law tem como principal fonte do direito os costumes, firmados pelos precedentes dos tribunais.

Nas palavras de Jorge Amaury Nunes, o direito inglês, marcado pelo sistema da common law, é caracterizado pelo fato de que, na ausência de norma escrita, os juízes tinham que formular uma decisão para o caso concreto ${ }^{19}$. Assim, diferentemente da família romano-germânica, na Inglaterra, a fonte principal do direito eram os costumes observados pela sociedade e a conduta social era regulada pela razão, ou por aquilo que os membros da sociedade entendiam como correto ${ }^{20}$.

Esse sistema teve sua formação entre os anos de 1066 e 1485, tendo início com a conquista normanda em 1066, pois levou para a Inglaterra um "poder forte, centralizado, rico de uma experiência administrativa posta à prova no ducado da Normandia" ${ }^{21}$. Assim, tem-se início o sistema feudal na Inglaterra.

É o feudalismo inglês de caráter militar, organizado, que vai permitir, por oposição ao continente europeu, o desenvolvimento da common law ${ }^{22}$. Surge, assim, o sistema da common law, ou direito comum, para fazer oposição aos costumes locais frutos do feudalismo ${ }^{23}$.

Embora os primeiros juízes da common law tenham aplicado regras de origem germânica - princípios que serviram de alicerce ao sistema jurídico inglês ${ }^{24}$-, verifica-se que "o sistema da common law, desde sua formatação inicial, era considerado tão adequado às necessidades e estava tão bem inserido na realidade social do seu tempo" ${ }^{25}$. Assim, José Rogério Cruz e Tucci explica que a "unidade jurídica, a configuração geográfica, a centralização judiciária e a homogeneidade da classe forense justificam a recepção falhada das fontes do direito romano-germânico na Inglaterra"26.

Além disso, observa Tucci que, na obra dos primeiros comentaristas da common law, já havia nítida preocupação com o problema dos julgamentos contraditórios, surgindo estudos sobre a importância de ater-se, na deci-

\footnotetext{
18 TUCCI, José Rogério Cruz e. Direito processual civil europeu contemporâneo. In: TUCCI, José Rogério Cruz e (Coord.). São Paulo: Lex Editora, 2010. p. 215.

19 NUNES, Jorge Amaury Maia. Op. cit., p. 120.

20 SABINO, Marco Antonio da Costa. Op. cit., fls. 51/72.

21 DAVID, René. Op. cit., p. 358.

22 DAVID, René. Op. cit., p. 358.

23 DAVID, René. Op. cit., p. 358.

24 TUCCI, José Rogério Cruz e. Precedente judicial como fonte de direito. São Paulo: RT, 2004, p. 152.

25 TUCCI, José Rogério Cruz e. Precedente judicial como fonte de direito. Op. cit., p. 150.

26 TUCCI, José Rogério Cruz e. Precedente judicial como fonte de direito. Op. cit., p. 151.
} 
são de casos similares, àqueles que já tinham sido antes decididos ${ }^{27}$. Por isso, destaca René David que "a common law foi criada pelos Tribunais Reais de Westminster" 28 , sendo, portanto, um direito jurisprudencial.

Esse direito jurisprudencial adquiriu uma autoridade diferente daquela obtida no continente europeu, já que "as regras que as decisões judiciárias estabeleceram devem ser seguidas, sob pena de destruírem toda a certeza" ${ }^{\prime 29} \mathrm{e}$ comprometerem a lógica do sistema da common law.

Dessa forma, verifica-se que, desde sua formação, a common law mostrou natural vocação para ser um sistema de case law, pois, embora ainda não houvesse um efeito vinculante ao precedente, os operadores do direito inglês já ressaltavam a relevância dos julgados e a importância de que tais decisões deviam ser seguidas para conferir certeza e continuidade ao direito ${ }^{30}$. Logo, nas lições de Jorge Amaury Nunes, desde o seu início, o sistema da common law foi orientado pelo brocado stare decisis et non quieta movere, isto é, "a formação da decisão judicial com arrimo em precedente de mesma natureza, eventualmente existente" ${ }^{\prime \prime 31}$.

\section{PRECEDENTE JUDICIAL NOS SISTEMAS DE COMMON LAW}

Embora se tenha falado anteriormente na ligação direta entre o sistema da common law com o sistema de precedentes, eles não se confundem. Ao se mencionar o sistema da common law, estar-se-á se referindo ao modelo de direito inglês, caracterizado por possuir como principal fonte os costumes, nascido como forma de oposição ao poder dos feudos pelos Reis ingleses.

Já o sistema do stare decisis refere-se ao modo de operacionalizar o sistema da common law, conferindo certeza a essa prática. É o denominado sistema de precedentes, que surgiu apenas no século $\mathrm{XVI}^{32}$. Assim, a teoria do stare decisis et non quieta movere, que significa literalmente mantenha-se a decisão e não mexa no que está quieto, está relacionada à ideia de que os juízes estão vinculados às decisões do passado, ou seja, aos precedentes ${ }^{33}$.

Explica René David que essa ideia do direito jurisprudencial de respeitar os precedentes lógicos nem sempre possuiu o mesmo grau de certeza e de segurança, já que somente após a primeira metade do século XIX a regra do

27 TUCCI, José Rogério Cruz e. Precedente judicial como fonte de direito. Op. cit., p. 153.

28 DAVID, René. Op. cit., p. 428.

29 DAVID, René. Op. cit., p. 428.

30 TUCCI, José Rogério Cruz e. Precedente judicial como fonte de direito. Op. cit., p. 154.

31 NUNES, Jorge Amaury Maia. Op. cit., p. 121.

32 SABINO, Marco Antonio da Costa. Op. cit., p. 61, fls. 51/72.

33 NOGUEIRA, Gustavo Santana. Stare decisis et non quieta movere: a vinculação aos precedentes no direito comparado e brasileiro. Rio de Janeiro: Lumen Juris, 2011. p. 162. 
precedente se estabeleceu rigorosamente, impondo aos juízes ingleses o recurso às regras criadas pelos seus predecessores34. Tal efeito vinculante restou reconhecido no julgamento do caso Beamisch v. Beamisch, em 1861, conduzido pelo Lord Campbell. Nesse caso restou determinado que a House of Lords estaria obrigada a acatar a sua própria autoridade proclamada nos julgamentos, em que:

O direito declarado na ratio decidendi, sendo claramente vinculante para todas as Cortes inferiores e todos os súditos do reino, se não fosse considerado igualmente vinculante para os Law Lords, a House of Lords se arrogaria o poder de alterar o direito e legiferar com autônoma autoridade. ${ }^{35}$

Percebe-se, então, que a teoria dos precedentes tem origem no costume, antiga base do sistema da common law ${ }^{36}$. Assim, o sistema da common law não se confunde com o sistema de precedentes, já que este é elemento que agregou operacionalização ao sistema da common law, conferindo certeza a essa prática.

Ademais, é importante ainda destacar que, além da força obrigatória do precedente (binding precedent), o sistema da common law também possuiu uma hierarquia funcional muito bem articulada ${ }^{37}$. Dessa forma, "o efeito vinculante das decisões já proferidas encontra-se condicionado à posição hierárquica do tribunal que as profere ${ }^{\prime 38}$. Nesse sentido, as decisões vinculam a própria Corte que a profere (eficácia interna), assim como todos os órgãos inferiores (eficácia externa).

Nesse sistema, pela técnica do precedente obrigatório, é, portanto, necessário que a Corte ou o juiz, ao decidir um caso concreto, fundamente sua decisão em uma decisão anterior ou em uma jurisprudência de tribunal superior ${ }^{39}$.

Nesse ponto, importante esclarecer qual a parte do precedente realmente vincula, pois afirmar que precedente vincula, na verdade, é dizer pouco ${ }^{40}$. Para tanto, devem ser separadas duas partes fundamentais de uma decisão judicial: a ratio decidendi (ou razões de decidir) e a obter dictum (ou dito para morrer, literalmente).

\footnotetext{
34 DAVID, René. Op. cit., p. 428.

35 Tucci, p. 220, apud.

36 SABINO, Marco Antonio da Costa. Op. cit., p. 60, fls. 51/72.

37 TUCCI, José Rogério Cruz e. Direito processual civil europeu contemporâneo. Op. cit., p. 223.

38 TUCCI, José Rogério Cruz e. Direito processual civil europeu contemporâneo. Op. cit., p. 223.

39 TUCCI, José Rogério Cruz e. Direito processual civil europeu contemporâneo. Op. cit., p. 223.

40 NOGUEIRA, Gustavo Santana. Op. cit., p. 168.
} 
Grande parte da doutrina brasileira e estrangeira que se dedicou a escrever sobre o tema é unânime em afirmar que apenas a ratio decidendi vincula, pois as questões de fato não se constituem em precedentes ${ }^{41}$. Entretanto, Gustavo Nogueira ressalta que "encontrar a ratio decidendi em um precedente não é tarefa nada fácil" ${ }^{42}$. Para fins desse estudo, para não prolongar as posições da doutrina sobre o conceito de ratio decidendi, considera-se ratio decidendi a regra ou proposição sem a qual o caso seria decidido de forma diversa, enquanto obter dictum seria tudo o que não está contido na ratio decidendił ${ }^{43}$.

Para melhor análise sobre a utilização do sistema de precedentes no direito inglês, importante trazer à baila as principais regras sobre a aplicação dos precedentes no sistema da common law: overruling e distinguishing.

Pela técnica do distinguishing, o juiz deve aproximar elementos objetivos dos casos que serviram como precedentes potencialmente e o caso em que pretende utilizá-los. Tal técnica permite ao juiz averiguar se o dado precedente pode ser utilizado no caso concreto a ser analisado ${ }^{44}$. Assim, de acordo com essa técnica, há uma valorização da ratio decidendi do procedente, que servirá para permitir sua aplicação ao caso concreto, caso existam semelhanças que justifiquem sua aplicação.

Já a técnica do overruling permite a atualização do precedente, pois o precedente que se mostrar ultrapassado com os fatos da sociedade ou equivocado pode ser substituído (overruling) por um novo precedente ${ }^{45}$. Assim, "fazer o overruling significa que o tribunal claramente sinaliza o fim da aplicação de uma regra de direito estabelecida pelo precedente" ${ }^{\prime \prime 6}$ e a substitui.

Nos Estados Unidos, por razões lógicas em decorrência da colonização inglesa, o sistema de precedentes adotado é muito semelhante ao modelo inglês. As decisões proferidas pelo mesmo órgão ou por órgão ao qual o Magistrado é ligado vinculam seus julgados, mas com uma importante exceção ${ }^{47}$. A Suprema Corte Federal e as Cortes Supremas Estaduais não estão vinculadas às suas próprias decisões, o que permite a esses tribunais reverem suas posições que se tornaram defasadas, por meio da técnica denominada overruling ${ }^{48}$.

\footnotetext{
41 NOGUEIRA, Gustavo Santana. Op. cit., p. 168.

42 NOGUEIRA, Gustavo Santana. Op. cit., p. 169.

43 NOGUEIRA, Gustavo Santana. Op. cit., p. 170.

44 SABINO, Marco Antonio da Costa. Op. cit., p. 65, fls. 51/72.

45 SABINO, Marco Antonio da Costa. Op. cit., p. 65, fls. 51/72.

46 NOGUEIRA, Gustavo Santana. Op. cit., p. 179.

47 RAMIRES, Maurício. Crítica à aplicação de precedentes no Direito brasileiro. Porto Alegre: Livraria do Advogado, 2010. p. 66

48 RAMIRES, Maurício. Op. cit., p. 66.
} 
Assim, ressalta, José Rogério Cruz e Tucci que a estrutura constitucional assentada no federalismo e na rígida divisão de poderes acarretou profundas diferenças com o sistema inglês ${ }^{49}$. Isso porque "os Estados Unidos se compõem uma federação, o que demanda uma rede judiciária extremamente intricada, à maneira como se formou o Judiciário brasileiro" ${ }^{\prime 50}$. Nesse país há uma forte dicotomia entre a justiça dos Estados e a justiça federal, onde cada estado conta com uma estrutura judiciária independente ${ }^{51}$.

No sistema judiciário norte-americano, o precedente sempre se forma nos tribunais, seja dos estados, seja da federação, e cada precedente é sempre formado por uma decisão majoritária do referido tribunal. Se não houver decisão da maioria, tem-se apenas um precedente persuasivo e não vinculante ${ }^{52}$. Além disso, o precedente apenas vincula a própria Corte que o formulou e os órgãos hierarquicamente subordinados a ela, já que o precedente sempre se formará nas Cortes de segunda instância. O único precedente que vincula todas as Cortes, em todas as instâncias inferiores, é o da Suprema Corte, por constituir a Corte mais alta do país ${ }^{53}$.

Logo, nos Estados Unidos, as fontes do direito não são apenas as regras herdadas da common law, mas também a Constituição, as leis federais e estaduais ${ }^{54}$. Além disso, como se verifica, os tribunais norte-americanos aplicam com menor rigidez a regra do binding precedent, pois eles, inclusive a própria Suprema Corte, reveem seus precedentes quando manifestamente equivocados ou ultrapassados ${ }^{55}$. Assim, observa-se uma flexibilização das regras adotadas no direito inglês pelo sistema norte-americano.

Interessante observar que o sistema norte-americano "é mais aberto à revisão dos precedentes", pois o juiz pode optar por não aplicar um precedente, "o que facilita as mudanças inerentes à evolução da sociedade" 56 . Por outro lado, o sistema inglês é muito mais rígido, não havendo essa opção ao juiz de escolher se aplica ou não um precedente, uma vez que "stare decisis na Inglaterra é tão conservador que há notícias de aplicação de precedentes de quatrocentos anos" ${ }^{\prime \prime}$.

Dessa breve análise, já é possível averiguar que o sistema de precedentes realmente confere uma maior previsibilidade e estabilidade ao direito e uma

TUCCI, José Rogério Cruz e. Precedente judicial como fonte de direito. Op. cit., p. 166, 165.

SABINO, Marco Antonio da Costa. Op. cit., p. 64, fls. 51/72.

SABINO, Marco Antonio da Costa. Op. cit., p. 64, fls. 51/72.

SABINO, Marco Antonio da Costa. Op. cit., p. 64, fls. 51/72.

SABINO, Marco Antonio da Costa. Op. cit., p. 64, fls. 51/72.

TUCCI, José Rogério Cruz e. Precedente judicial como fonte de direito. Op. cit., p. 166.

TUCCI, José Rogério Cruz e. Precedente judicial como fonte de direito. Op. cit., p. 167.

SABINO, Marco Antonio da Costa. Op. cit., p. 65, fls. 51/72.

Apud SABINO, Marco Antonio da Costa. Op. cit., p. 65, fls. 51/72.
} 
maior segurança jurídica à sociedade ${ }^{58}$. Diante disso, indaga-se: seria possível a aplicação desse sistema de precedentes, já que confere segurança e estabilidade ao Direito brasileiro?

\section{A FORMAÇÃO DO PROCESSO DECISÓRIO NO SISTEMA DA COMMON LAWNOS ESTADOS UNIDOS}

Explica Benjamin Cardozo, em sua análise sobre a construção do direito pelo juiz, que é preciso distinguir entre elementos conscientes e subconscientes que estão presentes na formação da decisão pelo juiz ${ }^{59}$. Assim, segundo ele, os elementos subconscientes são "as forças colocadas abaixo da superfície" que impulsionam continuamente o juiz, como institutos herdados, crenças tradicionais, convicções adquiridas, que resulta em uma noção de vida, em uma concepção das necessidades sociais, além de possibilitar que as decisões do juiz estejam sempre coerentes consigo mesmo e incoerentes com a dos outros juízes ${ }^{60}$.

Por conseguinte, tendo em vista que as fontes do direito norte-americano é a lei e a jurisprudência, os costumes, Cardozo explica que, diante do silêncio da lei, que é a denominada "região do mistério", o juiz dirige sua atenção à common law ${ }^{61}$. Nesse ponto, então, o juiz compara o presente caso com os precedentes judiciários acumulados em sua memória.

Diante desse cenário, explica Cardozo que o problema enfrentado pelo juiz tem um duplo problema: primeiro, ele tem a tarefa de extrair do precedente a ratio decidendi e, depois, determinar o sentido ou a direção em que este princípio deverá mover-se desenvolver-se ${ }^{62}$.

Observa-se, assim, que a tarefa de decidir as causas de acordo com os precedentes judiciários é um processo semelhante ao de decidir consoante a lei.

\section{A VINCULAÇÃO AOS PRECEDENTES NO DIREITO BRASILEIRO}

Após a breve análise sobre o funcionamento e a estrutura do stare decisis, esse tópico procura analisar a possibilidade de sua aplicação no Direito brasileiro. Historicamente no Brasil a jurisprudência não tinha senão uma autoridade doutrinária e moral, já que a Constituição de 1824, em seu art. 72, e a Constituição de 1891, "já determinava que ninguém estava obrigado a fazer ou deixar de fazer alguma coisa a não ser em virtude de lei, e o Poder Judiciário, no Brasil, nunca teve função legislativa ${ }^{63}$. E, somente em 1926, o Supremo Tribunal Fede-

58 SABINO, Marco Antonio da Costa. Op. cit., p. 65, fls. 51/72.

59 CARDOZO, Benjamin. A natureza do processo e a evolução do direito. $4^{\text {a }}$ Conferência - Adesão ao precedente. O elemento subconsciente no processo judicial. São Paulo: Nacional de Direito, 1956. p. 02.

60 CARDOZO, Benjamin. Op. cit., p. 03.

61 CARDOZO, Benjamin. Op. cit., p. 06.

62 CARDOZO, Benjamin. Op. cit., p. 12.

63 STRECK, Lenio Luiz. Op. cit., p. 80. 
ral passou a ter função unificadora, relativamente à jurisprudência nacional, por meio do recurso extraordinário ${ }^{64}$.

Como observa Jorge Amaury Nunes, "nos ordenamentos de civil law (especialmente no caso brasileiro), a compreensão do fenômeno relativo à decisão judicial vinculante voltou à ordem do dia", a partir da edição da Emenda Constitucional $\mathrm{n}^{-}$3, que instituiu a ação declaratória de inconstitucionalidade e o efeito vinculante de suas decisões ${ }^{65}$.

Nesse sentido, entende Bruno Periolo Odahara que, observando o caso do Direito brasileiro, verifica-se que "uma série de medidas vem sendo tomadas nos últimos anos nas reformas processuais e constitucionais com vistas a uma uniformização do entendimento jurisprudencial"66, como se verifica no disposto no art. 475, § 3을 do Código de Processo Civil ${ }^{67}$, e também no art. 103-A da Constituição de $1988^{68}$. É possível ainda citar outros dispositivos que podem se aproximar do sistema de precedentes: tem-se o art. 105 da Constituição de $1988^{69}$, que estipulou a missão do STJ de uniformizar a jurisprudência sobre aplicação da lei federal; o art. 557 do $\mathrm{CPC}^{70}$, o art. 285-A do $\mathrm{CPC}^{71}$, o art. 518, $\S 1^{\mathrm{o}}$, do $\mathrm{CPC}^{72}$ e outros.

Entre esses exemplos, os dispositivos do Direito brasileiro que mais se aproximam do sistema de precedentes do direito inglês é a súmula vinculante,

64 STRECK, Lenio Luiz. Op. cit., p. 82.

65 NUNES, Jorge Amaury Maia. Op. cit., p. 105.

66 ODAHARA, Bruno Periolo. Um rápido olhar sobre o stare decisis. Processos coletivos, Porto Alegre, v. 2, n. 03, p. $72,1^{\circ}$ jul. 2011.

67 "Art. 475. Está sujeita ao duplo grau de jurisdição, não produzindo efeito senão depois de confirmada pelo tribunal, a sentença: [...] § $3^{\circ}$ Também não se aplica o disposto neste artigo quando a sentença estiver fundada em jurisprudência do plenário do Supremo Tribunal Federal ou em súmula deste Tribunal ou do tribunal superior competente."

68 NUNES, Jorge Amaury Maia. Op. cit., p. 154.

69 "Art. 105. Compete ao Superior Tribunal de Justiça: [...] III - julgar, em recurso especial, as causas decididas, em única ou última instância, pelos Tribunais Regionais Federais ou pelos tribunais dos Estados, do Distrito Federal e Territórios, quando a decisão recorrida: a) contrariar tratado ou lei federal, ou negar-lhes vigência; b) julgar válido ato de governo local contestado em face de lei federal; c) der a lei federal interpretação divergente da que lhe haja atribuído outro tribunal."

70 "Art. 557. O relator negará seguimento a recurso manifestamente inadmissível, improcedente, prejudicado ou em confronto com súmula ou com jurisprudência dominante do respectivo tribunal, do Supremo Tribunal Federal, ou de Tribunal Superior. $\S 1^{\circ}-$ A. Se a decisão recorrida estiver em manifesto confronto com súmula ou com jurisprudência dominante do Supremo Tribunal Federal, ou de Tribunal Superior, o relator poderá dar provimento ao recurso. $\S 1^{\circ}$ Da decisão caberá agravo, no prazo de cinco dias, ao órgão competente para o julgamento do recurso, e, se não houver retratação, o relator apresentará o processo em mesa, proferindo voto; provido o agravo, o recurso terá seguimento. $\S 2^{\circ}$ Quando manifestamente inadmissível ou infundado o agravo, o tribunal condenará o agravante a pagar ao agravado multa entre um e dez por cento do valor corrigido da causa, ficando a interposição de qualquer outro recurso condicionada ao depósito do respectivo valor."

71 "Art. 285-A. Quando a matéria controvertida for unicamente de direito e no juízo já houver sido proferida sentença de total improcedência em outros casos idênticos, poderá ser dispensada a citação e proferida sentença, reproduzindo-se o teor da anteriormente prolatada."

72 "Art. 518. Interposta a apelação, o juiz, declarando os efeitos em que a recebe, mandará dar vista ao apelado para responder. $\S 1^{\circ} 0$ juiz não receberá o recurso de apelação quando a sentença estiver em conformidade com súmula do Superior Tribunal de Justiça ou do Supremo Tribunal Federal." 
prevista no art. 103-A da Constituição de 1988, e o efeito vinculante atribuído às ações direta de inconstitucionalidade e à ação declaratória de constitucionalidade ${ }^{73}$.

Diferentemente das ações direta de inconstitucionalidade e declaratória de constitucionalidade, nas súmulas vinculantes "não se estará diante do mesmo tipo de processo objetivo" ${ }^{14}$, pois não se terá um processo subjetivo, entre partes, nem um processo objetivo nos moldes do controle concentrado. O procedimento para edição das súmulas vinculantes possui alguns requisitos: a) a legitimidade para propor o debate sobre a súmula; b) necessidade de haver reiteradas decisões sobre matéria constitucional; c) controvérsia atual entre os órgão do judiciário ou entre estes e a Administração Pública; e d) a edição das súmulas tem por objeto a validade, a interpretação e a eficácia de normas determinadas ${ }^{75}$.

Ainda sobre o caráter vinculante das súmulas vinculantes, elas obrigam todos os demais órgãos do Poder Judiciário, exceto o Supremo Tribunal Federal, além de vincular o Poder Legislativo e a Administração Pública. A Emenda Constitucional $n^{\circ}$ 45, de 2004, que criou a súmula vinculante ${ }^{76}$, ainda previu a possibilidade de revisão ou cancelamento da súmula, para evitar o possível engessamento ou estagnação do direito. Esses institutos se aproximam das técnicas do overruling e do distinguishing, que também permitem a atualização do precedente.

Além do disposto na Constituição, o Direito brasileiro ainda possui mecanismo processual de uniformização da jurisprudência, previsto nos arts. 476 a 479 do Código de Processo Civil. Segundo José Rogério Tucci, esse mecanismo não é um recurso, mas sim um incidente processual "suscitável por qualquer juiz da turma julgadora ou por um dos litigantes" ${ }^{\prime 77}$. O objetivo desse incidente é "provocar o prévio pronunciamento do tribunal de segundo ou superior grau acerca da interpretação de determinada tese ou norma jurídica" ${ }^{78}$, se houver divergência com relação a ela.

Entretanto, anota Tucci que esse incidente não é muito utilizado pelos tribunais regionais federais e estaduais, já que eles se submetem às decisões, mesmo sumuladas, proferidas pelo Superior Tribunal de Justiça e Supremo Tribunal Federal79. Isso porque, no modelo brasileiro, "os precedentes sumulados gozam de vigorosa força persuasiva ${ }^{80}$.

73 NUNES, Jorge Amaury Maia. Op. cit., p. 137.

74 NUNES, Jorge Amaury Maia. Op. cit., p. 144.

75 NUNES, Jorge Amaury Maia. Op. cit., p. 146/147.

76 NUNES, Jorge Amaury Maia. Op. cit., p. 153.

$77 \mathrm{TUCCl}$, José Rogério Cruz e. Precedente judicial como fonte de direito. Op. cit., p. 259.

$78 \mathrm{TUCCl}$, José Rogério Cruz e. Precedente judicial como fonte de direito. Op. cit., p. 259.

79 TUCCI, José Rogério Cruz e. Precedente judicial como fonte de direito. Op. cit., p. 259.

80 TUCCl, José Rogério Cruz e. Precedente judicial como fonte de direito. Op. cit., p. 259. 
Outro mecanismo do Direito brasileiro é o previsto no art. 557, § $1^{\circ}-\mathrm{A}$, do CPC, que dispõe se "a decisão recorrida estiver em confronto com súmula ou com jurisprudência dominante do Supremo Tribunal Federal ou de tribunal superior, o relator poderá dar provimento ao recurso". Observa Tucci que, diante desse dispositivo, os efeitos vinculantes dos precedentes chegam até a autorizar que a decisão monocrática substitua o tradicional julgamento colegiado de segundo grau ${ }^{81}$.

Nesse sentido, Sérgio Bermudes ainda entende que o art. 557, § 1-A A do CPC é mais uma avanço da legislação brasileira no sentido de tornar efetiva a jurisprudência ${ }^{82}$.

Todos esses exemplos permitem a existência de sistema de vinculação a decisões já proferidas por outros órgãos ou no passado, tal como se verificou no direito inglês, por meio do sistema dos precedentes. Entretanto, observa-se que a adoção de tais mecanismos não possibilita a conclusão de que o Direito brasileiro adota o sistema dos precedentes. Explica Bruno Periolo Odahara que há duas distinções muito claras entre as concepções típicas da common law e sua aplicação no Direito brasileiro.

Primeiramente, no Brasil, a formação de jurisprudência ou das súmulas depende de decisões reiteradas sobre mesmo assunto, enquanto que a formação de um precedente no direito inglês depende apenas de uma única decisão judicial. E, segundo, porque a vinculação das decisões no Direito brasileiro é exercido quase que de forma exclusivamente vertical, enquanto que no sistema da common law essa vinculação ocorre também no campo horizontal ${ }^{83}$.

Outro aspecto que merece destaque para distinguir o sistema adotado no direito inglês do ordenamento jurídico brasileiro diz respeito às fontes do direito. Na Inglaterra, os costumes foram as principais fontes do direito, daí por que o direito inglês é denominado como consuetudinário ${ }^{84}$. Já no Direito brasileiro, que recepcionou grande parte dos institutos do modelo da civil law, as leis foram e ainda são as principais fontes do direito ${ }^{85}$. Assim, no Brasil, os costumes funcionam apenas como fonte supletivas para suprir lacunas na lei ${ }^{86}$.

Dessa análise já se verifica outra diferença substancial entre o sistema de precedentes inglês e o direito sumular brasileiro. No direito inglês, tipicamente consuetudinário, as normas positivas que determinam a vinculação a um

81 TUCCI, José Rogério Cruz e. Precedente judicial como fonte de direito. Op. cit., p. 262.

82 BERMUDES, Sérgio. Op. cit., p. 115.

83 ODAHARA, Bruno Periolo. Op. cit., p. 73.

84 SABINO, Marco Antonio da Costa. Op. cit., p. 54, fls. 51/72.

85 ODAHARA, Bruno Periolo. Op. cit., p. 54.

86 Nos termos do art. $4^{\circ}$ da Lei de Introdução às Normas do Direito Brasileiro: "Quando a lei for omissa, o juiz decidirá o caso de acordo com a analogia, os costumes e os princípios gerais de direito". 
precedente decorrem do próprio sistema da common law, pois são os próprios precedentes que determinam sua vinculação.

Já no Direito brasileiro, país originário do sistema romano-germânico, só se admitiu a existência de súmulas vinculantes após a positivação desse instituto em normas escritas, como na Constituição e em leis federais. Assim, a adoção de um sistema de precedentes no Direito brasileiro não decorre da cultura existente no país, mas apenas de uma importação de um instituto bem-sucedido em um direito estrangeiro.

Nesse sentido, Gustavo Santana Nogueira afirma que "jamais tivemos uma cultura que valorizasse os precedentes" ${ }^{\prime \prime 7}$. Segundo o autor, tal prática se inicia nas faculdades de Direito, onde se ensinam e se estudam as regras do direito positivado, e não como tal direito é visto pelos tribunais, e ainda indaga: "Se nem mesmo os tribunais respeitam os seus precedentes, por que as universidades fariam o estudo de algo que muda constantemente?"88

Nessas palavras o autor resume a realidade do Direito brasileiro que, embora possua inúmeras regras jurídicas que buscam a uniformidade das decisões, bem como sua segurança e previsibilidade; os próprios tribunais não conseguem compreender o fenômeno da vinculação aos precedentes, seja por meio das regras positivadas pelo Direito brasileiro, seja pela ausência de observação das suas próprias decisões ${ }^{89}$.

Por outro lado, Sergio Bermudes entende que a instituição da súmula vinculante por meio do art. 103-A da Constituição Federal de 1988 buscou resolver, em parte, o gravíssimo problema dos reiterados desafios à jurisprudência assente de um tribunal por julgamento e recursos contrários a ela ${ }^{90}$. O autor ainda observou que a Emenda Constitucional no 45, de 2004, que institui a súmula vinculante, foi prudente ao criar um alcance limitado.

Outro problema que dificulta a adoção do sistema de precedentes no Direito brasileiro está relacionado ao papel desempenhado pelos juízes. $\mathrm{Na}$ Inglaterra, os juízes sempre foram vistos como verdadeiros criados do direito ${ }^{91}$. Já no Brasil, por muito tempo e até os dias atuais, o papel de criação pelo juiz é visto com muitas críticas pela doutrina, embora hoje existam mais estudos que tratam do papel criador desempenhado pelos juízes.

Apenas para ilustrar, pois esse tema é muito polêmico e permite inúmeros desdobramentos que podem comprometer o objeto de estudo desse traba-

87 NOGUEIRA, Gustavo Santana. Op. cit., p. 219.

88 NOGUEIRA, Gustavo Santana. Op. cit., p. 220.

89 NOGUEIRA, Gustavo Santana. Op. cit., p. 220.

90 BERMUDES, Sérgio. Op. cit., p. 115.

91 ODAHARA, Bruno Periolo. Op. cit., p. 57. 
Iho, a primeira crítica que se faz ao fato de o juiz ser criador do direito é pela falta de legitimidade de suas decisões, pois viola o princípio democrático ${ }^{92}$. Além disso, a atuação positiva do juiz também violaria o princípio da separação dos poderes; assim, o Judiciário, ao inovar no ordenamento jurídico, estaria se desviando de sua finalidade institucional.

Pois bem, embora esse tema possa ser muito mais discutido, tais argumentos permitem observar que o tema da atividade de criação desempenhada pelo juiz no Direito brasileiro é muito controverso e não há um consenso entre doutrinadores.

Gustavo Santana Nogueira ainda apresenta outro ponto que dificulta a busca pela segurança jurídica no Direito brasileiro: a mudança da composição dos membros dos tribunais superiores, especificamente do Superior Tribunal de Justiça e do Supremo Tribunal Federal ${ }^{93}$. Como visto, no direito inglês e no direito norte-americano, sequer os doutrinadores tocam nesse assunto, já que as possibilidades existentes nesses sistemas jurídicos para alteração, atualização e superação de um precedente são exceções e raramente ocorrem.

\section{CONCLUSÕES}

1. A busca de maior segurança nas decisões judiciais e a otimização destas, evitando-se o desnecessário exame de casos idênticos já anteriormente decididos e, consequentemente, por uma maior segurança jurídica em prol da sociedade, levou vários países a adotarem mecanismos com o objetivo de uniformizar a jurisprudência.

2. Para solucionar esse problema no ordenamento jurídico brasileiro, seria possível adoção do sistema de precedentes, originário do modelo do common law, no Direito brasileiro, no qual se adota o modelo do civil law, com o objetivo de garantir a segurança jurídica?

3. Para iniciar esse estudo, dividiu-se o estudo do Direito com base nas família romano-germânica, na da common law e na da civil law. A família romano-germânica agrupa os países que tiveram a ciência do direito concebida sobre a base do direito romano, tendo seu berço na Europa. Essa família caracteriza-se pelo fato de suas regras de direito serem concebidas como regras de conduta, ligadas a preocupações morais e de justiça, além de elaborarem seus direitos visando à regulação das relações entre os cidadãos.

4. O ordenamento jurídico brasileiro, filiado ao sistema romano-germânico, devido à colonização portuguesa, sofreu um movimento similar ao orde-

92 ODAHARA, Bruno Periolo. Op. cit., p. 57.

93 NOGUEIRA, Gustavo Santana. Op. cit., p. 220. 
namento jurídico da França e da Alemanha, que pretendiam construir o Direito baseado no code. Portanto, no Direito brasileiro, a rigor, a fonte primordial é a lei.

6. Já a família da common law, típica do direito inglês, tem como principal fonte do direito os costumes, firmados pelos precedentes dos tribunais e caracterizado pelo fato de que, na ausência de norma escrita, os juízes tinham que formular uma decisão para o caso concreto. Assim, diferentemente da família romano-germânica, na Inglaterra, a fonte principal do direito eram os costumes observados pela sociedade e a conduta social era regulada pela razão, ou por aquilo que os membros da sociedade entendiam como correto.

7. O sistema da common law foi orientado pelo brocado stare decisis et non quieta movere, que significa literalmente mantenha-se a decisão e não mexa no que está quieto, está relacionada à ideia de que os juízes estão vinculados às decisões do passado, ou seja, aos precedentes.

8. O sistema da common law também possuiu uma hierarquia funcional muito bem articulada, em que o efeito vinculante das decisões já proferidas encontra-se condicionado à posição hierárquica do tribunal que as profere. Nesse sentido, as decisões vinculam a própria Corte que a profere (eficácia interna), assim como todos os órgãos inferiores (eficácia externa).

9. Nos Estados Unidos, por razões lógicas em decorrência da colonização inglesa, o sistema de precedentes adotado é muito semelhante ao modelo inglês. As decisões proferidas pelo mesmo órgão ou por órgão ao qual o Magistrado é ligado vinculam seus julgados, mas com uma importante exceção. A Suprema Corte Federal e as Cortes Supremas Estaduais não estão vinculadas às suas próprias decisões, o que permite a esses tribunais reverem suas posições que se tornaram defasadas, por meio da técnica denominada overruling.

10. No caso do Direito brasileiro, verifica-se que uma série de medidas vem sendo tomadas nos últimos anos nas reformas processuais e constitucionais com vistas a uma uniformização do entendimento jurisprudencial, como se verifica no disposto no art. 475, § 3ํㅡㄹ do Código de Processo Civil, e também no art. 103-A da Constituição de 1988. É possível ainda citar outros dispositivos que podem se aproximar do sistema de precedentes: tem-se o art. 105 da Constituição de 1988, que estipulou a missão do STJ de uniformizar a jurisprudência sobre aplicação da lei federal; o art. 557 do CPC, o art. 285-A do CPC, o art. 518, § $1^{\circ}$, do CPC e outros. Todos esses exemplos permitem a existência de sistema de vinculação a decisões já proferidas por outros órgãos ou no passado, tal como se verificou no direito inglês, por meio do sistema dos precedentes. Entretanto, observa-se que a adoção de tais mecanismos não possibilita a conclusão de que o Direito brasileiro adota o sistema dos precedentes. 
11. Primeiramente porque, no Brasil, a formação de jurisprudência ou das súmulas depende de decisões reiteradas sobre mesmo assunto, enquanto que a formação de um precedente no direito inglês depende apenas de uma única decisão judicial. E, segundo, porque a vinculação das decisões no Direito brasileiro é exercido quase que de forma exclusivamente vertical, enquanto que, no sistema da common law, essa vinculação ocorre também no campo horizontal.

12. Na Inglaterra, os costumes foram as principais fontes do direito. Já no Direito brasileiro, que recepcionou grande parte dos institutos do modelo da civil law, as leis foram e ainda são as principais fontes do direito. Assim, no Brasil, os costumes funcionam apenas como fonte supletivas para suprir lacunas na lei.

13. Enquanto no direito inglês, tipicamente consuetudinário, as normas positivas que determinam a vinculação a um precedente decorrem do próprio sistema da common law, no Direito brasileiro, país originário do sistema romano-germânico, só se admitiu a existência de súmulas vinculantes após a positivação desse instituto em normas escritas, como na Constituição e em leis federais.

14. A adoção de um sistema de precedentes no Direito brasileiro não decorre da cultura existente no país, mas apenas de uma importação de um instituto bem-sucedido em um direito estrangeiro.

\section{REFERÊNCIAS}

BARROSO, Luís Roberto. Neoconstitucionalismo e constitucionalização do Direito. Brasília: Escola Nacional dos Magistrados, 2006.

BERMUDES, Sérgio. A reforma judiciária pela Emenda Constitucional $n^{\circ}$ 45: observações aos artigos da Constituição alterados pela Emenda Constitucional no ${ }^{45}$, de 8 de dezembro de 2004. Rio de Janeiro: Forense, 2005.

CARDOZO, Benjamin. A natureza do processo e a evolução do direito. $4^{\text {a }}$ Conferência - Adesão ao precedente. O elemento subconsciente no processo judicial.

São Paulo:Nacional de Direito, 1956.

DAVID, René. Os grandes sistemas do direito contemporâneo. 2. ed. Lisboa: Meridiano, 1978.

LOPES, José Reinaldo de Lima. O direito na história: lições introdutórias. 4. ed. São Paulo: Atlas, 2012.

NOGUEIRA, Gustavo Santana. Stare decisis et non quieta movere: a vinculação aos precedentes no direito comparado e brasileiro. Rio de Janeiro: Lumen Juris, 2011.

NUNES, Jorge Amaury Maia. Segurança jurídica e súmula vinculante. São Paulo: Saraiva, 2010. 
ODAHARA, Bruno Periolo. Um rápido olhar sobre o stare decisis. Processos coletivos, Porto Alegre, v. 2, n. 03, 1o jul. 2011.

RAMIRES, Maurício. Crítica à aplicação de precedentes no Direito brasileiro. Porto Alegre: Livraria do Advogado, 2010.

SABINO, Marco Antonio da Costa. O precedente jurisdicional vinculante e sua força no Brasil. Revista Dialética de Direito Processual Civil, n. 85, abr. 2010, fls. 51/72.

STRECK, Lenio Luiz. Súmulas no Direito brasileiro: eficácia, poder e função: a ilegitimidade constitucional do efeito vinculante. 2. ed. Porto Alegre: Livraria do Advogado, 1998.

TUCCI, José Rogério Cruz e. Precedente judicial como fonte de direito. São Paulo: RT, 2004.

. Direito processual civil europeu contemporâneo. In: TUCCI, José Rogério Cruz e (Coord.). São Paulo: Lex Editora, 2010. 


\title{
Equilibrio Democrático e Controle Social: o Controle dos Atos de Gestão da Administração Pública por Meio da Participação Popular
}

\author{
Balance the Democratic and Social Control: the Control of the Board of \\ Management of Public Acts Through Popular Participation
}

\section{CAROLLINE LEAL RIBAS}

Mestranda em Estudos Culturais Contemporâneos pela Fumec, Especialista em Direito Público pela PUC-Minas e em Gestão Pública pela UEMG, Assessora Jurídica do Estado de Minas Gerais.

Submissão: 15.05 .2015

Decisão Editorial: 25.06.2015

Comunicação ao autor: 25.06 .2015

RESUMO: 0 presente artigo tem como objetivo analisar o fenômeno do controle social e os desafios para sua efetivação no contexto da democracia participativa expressa pela Constituição Federal de 1988. Para tanto, descrevem-se, inicialmente, os controles clássicos da Administração Pública, a fim de se evidenciar que o controle interno e externo, muitas vezes, são insuficientes para se garantir uma fiscalização transparente e efetiva sob os atos de gestão. Em seguida, passou-se a enfatizar novas formas de controle, oriundas do controle social, a fim de se permitir que a sociedade atue, de forma ativa e colaborativa, complementando os controles tradicionais. 0 controle social consiste em um direito público subjetivo de fiscalização e controle da população sobre as atividades decorrentes da função administrativa do Estado. A problematização versa na discussão acerca da eficácia e efetividade deste controle, uma vez que, embora haja vários instrumentos para promovê-lo, ainda existe uma resistência por parte do Poder Público e por parte dos cidadãos quanto à participação popular nas decisões estatais. Percebe-se que, na sociedade brasileira, não existe uma cultura de participação ativa da população na seara administrativa, sendo necessária uma ampliação da interface entre os gestores e o cidadão, o que demanda um processo de conscientização e educação para formação de uma cultura cívica. É nesse contexto que propõe uma reflexão acerca dos desafios para a efetivação de controle, como meio de se garantir a verdadeira democracia participativa, embasada nos princípios da cidadania e da boa governança.

PALAVRAS-CHAVE: Administração Pública; democracia participativa; novos controles; transparência.

ABSTRACT: This article aims to analyze the social control of the phenomenon and the challenges for its implementation in the context of participatory democracy expressed by the Constitution of 1988. They describe themselves, initially, the classic controls of Public Administration, in order to show that the internal and external control, are often insufficient to ensure a transparent and effective monitoring in the management acts. Then we started to emphasize new forms of control, originated in the social control, in order to allow society to act actively and collaboratively, complementing traditional 